\title{
Development of Thin Film Amorphous Silicon Tandem Junction Based Photocathodes Providing High Open-Circuit Voltages for Hydrogen Production
}

\author{
F. Urbain, ${ }^{1}$ K. Wilken, ${ }^{1}$ V. Smirnov, ${ }^{1}$ O. Astakhov, ${ }^{1}$ A. Lambertz, ${ }^{1}$ J.-P. Becker, ${ }^{1}$ \\ U. Rau, ${ }^{1}$ J. Ziegler, ${ }^{2}$ B. Kaiser, ${ }^{2}$ W. Jaegermann, ${ }^{2}$ and F. Finger ${ }^{1}$ \\ ${ }^{1}$ IEK-5 Photovoltaik, Forschungszentrum Jülich, 52425 Jülich, Germany \\ ${ }^{2}$ Institute of Materials Science, TU Darmstadt, 64287 Darmstadt, Germany \\ Correspondence should be addressed to F. Urbain; f.urbain@fz-juelich.de
}

Received 13 March 2014; Revised 24 June 2014; Accepted 30 June 2014; Published 16 July 2014

Academic Editor: Wenjun Luo

Copyright (c) 2014 F. Urbain et al. This is an open access article distributed under the Creative Commons Attribution License, which permits unrestricted use, distribution, and reproduction in any medium, provided the original work is properly cited.

\begin{abstract}
Hydrogenated amorphous silicon thin film tandem solar cells (a-Si:H/a-Si:H) have been developed with focus on high open-circuit voltages for the direct application as photocathodes in photoelectrochemical water splitting devices. By temperature variation during deposition of the intrinsic a-Si:H absorber layers the band gap energy of a-Si:H absorber layers, correlating with the hydrogen content of the material, can be adjusted and combined in a way that a-Si:H/a-Si:H tandem solar cells provide open-circuit voltages up to $1.87 \mathrm{~V}$. The applicability of the tandem solar cells as photocathodes was investigated in a photoelectrochemical cell (PEC) measurement set-up. With platinum as a catalyst, the a-Si:H/a-Si:H based photocathodes exhibit a high photocurrent onset potential of $1.76 \mathrm{~V}$ versus the reversible hydrogen electrode (RHE) and a photocurrent of $5.3 \mathrm{~mA} / \mathrm{cm}^{2}$ at $0 \mathrm{~V}$ versus RHE (under halogen lamp illumination). Our results provide evidence that a direct application of thin film silicon based photocathodes fulfills the main thermodynamic requirements to generate hydrogen. Furthermore, the presented approach may provide an efficient and low-cost route to solar hydrogen production.
\end{abstract}

\section{Introduction}

Solar based hydrogen production via photoelectrochemical water splitting provides an alluring route to convert solar energy into a storable and clean chemical fuel and, therefore, increasingly plays a decisive role in sustainable energy concepts $[1,2]$. Among the current variety of photoelectrode absorber materials for integrated water splitting devices, including III-V semiconductors [3-6], metal oxides [7-9], or crystalline silicon [10-12], amorphous silicon thin films emerge as a novel promising candidate $[9,13-16]$. Overall, thin film silicon technology stands out as an attractive choice for water splitting applications, because it combines low-cost production, earth abundance, and versatility [17]

Amorphous silicon tandem solar cells have been intensively developed in the past, with major focus on high conversion efficiencies [18]. In our approach here, however, the focus is on the development of high $V_{\mathrm{OC}}$ devices, suitable for water splitting applications. Therefore, we will describe a development route to achieve high voltage devices and emphasize which particular parameter regimes are optimal in order to achieve high open-circuit voltages in a-Si:H/a$\mathrm{Si}: \mathrm{H}$ tandem junction solar cells. Additionally it will be shown that the parameters can be systematically adjusted to tune the $V_{\mathrm{OC}}$ values in the range between $1.60 \mathrm{~V}$ and $1.87 \mathrm{~V}$, which is relevant if one considers various PEC systems with different overpotential losses, that is, when different voltage requirements are implied. The major part of the reported a$\mathrm{Si}: \mathrm{H}$ tandem solar cells for water splitting applications was merely designed to provide additional bias to a photoactive metal oxide electrode $[9,14,16]$. In contrast, this study reports on the direct application of the a-Si:H tandem solar cells as all-silicon photoelectrodes for driving the water splitting reactions.

Regarding solar assisted water electrolysis and the concomitant requirement of electrochemical potentials, that is, 
photovoltages above 1.23 V (disregarding overpotentials) [1921], photocathodes providing high photocurrent at high voltages are desirable. Concerning this, great importance is given to the versatility of the a-Si:H material. By changing deposition process parameters, the electronic and optical properties of the a-Si:H absorber material can be adjusted, such that a wide range of high open-circuit voltages is provided in a$\mathrm{Si}: \mathrm{H}$ based single junction solar cells, without significantly impairing current densities [22, 23]. In comparison, other photocathode material systems listed above often suffer from rather low photovoltages and therefore limit the solar to hydrogen efficiency. The open-circuit voltage of a properly designed solar cell mainly depends on the band gap of the absorber layer. Thus, attempts for the variation in band gap energy of intrinsic a-Si: $\mathrm{H}$ absorber layers were made in this study. In real photoelectrochemical assemblies, the potential losses inevitably exceed $200 \mathrm{mV}$, depending on the current densities and catalysts used [24,25]. Thus, for self-contained solar water splitting devices photovoltages of at least $1.43 \mathrm{~V}$ are needed. In this manner, a-Si:H based solar cells are very beneficial, because the electronic properties of individual a$\mathrm{Si}: \mathrm{H}$ absorber layers can be combined by connecting two single junction cells (subcells) in series. In this configuration a-Si:H/a-Si:H tandem junction solar cells promote a further extended range of achievable high voltages $[26,27]$. Thus, they may satisfy the specific thermodynamic requirements of different photoelectrochemical systems.

Based on (photo-)electrochemical experiments, the performance and stability of the developed a-Si:H/a-Si:H tandem junction based photocathodes were evaluated with respect to the hydrogen evolution reaction (HER). Moreover, to fully explore the performance of the photocathode, platinum was evaporated as a catalyst.

\section{Experimental Details}

2.1. Preparation of a-Si:H Layers and Solar Cells. All a-Si:H layers were deposited by a plasma enhanced chemical vapor deposition (PECVD) technique in a multichamber system. For the intrinsic a-Si:H absorber layers a mixture of silane $\left(\mathrm{SiH}_{4}\right)$ and hydrogen $\left(\mathrm{H}_{2}\right)$ gases was used. For the n- and p-type layers, trimethylborane (TMB), methane $\left(\mathrm{CH}_{4}\right)$, and phosphine $\left(\mathrm{PH}_{3}\right)$ gases were added to the silane-hydrogen mixture. An excitation frequency of $13.56 \mathrm{MHz}$ was applied for all depositions. The a-Si:H material optimization was mainly performed as a function of the substrate temperature $T_{s}$ and silane concentration SC, defined as the ratio between the $\mathrm{SiH}_{4}$ flow and the total gas flow. Single junction and tandem junction solar cells were made in a p-i-n and in a $\mathrm{p}-\mathrm{i}-\mathrm{n}-\mathrm{p}-\mathrm{i}-\mathrm{n}$ superstrate configuration, respectively, with a sputtered zinc oxide/silver $(\mathrm{ZnO} / \mathrm{Ag})$ reflecting back contact [28] defining the area $\left(1 \mathrm{~cm}^{2}\right)$ of the individual cells. The thickness of the intrinsic a-Si:H layer in single junction solar cells was kept constant at $400 \mathrm{~nm}$. In the standard tandem device, the bottom cell thickness was $400 \mathrm{~nm}$ and the top cell thickness was $110 \mathrm{~nm}$. The $\mathrm{p}$ - and $\mathrm{n}$-doped layers are the same for all fabricated solar cells and are deposited at a substrate temperature of $180^{\circ} \mathrm{C}$. Since $T_{s}$ is varied for the deposition of the intrinsic a-Si:H layer, a waiting time of 30

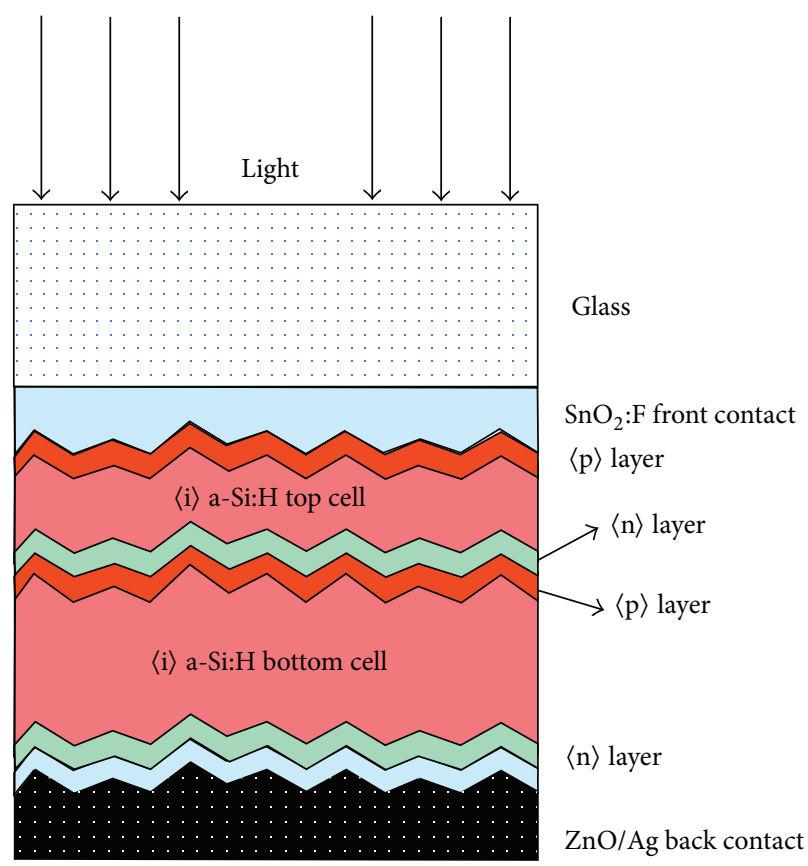

FIGURE 1: Schematic drawing of the layer stack used for the deposition of a-Si:H/a-Si:H tandem solar cells.

minutes between the layer deposition was implemented in order to maintain a required temperature of the substrate. All solar cells were deposited on $100 \mathrm{~cm}^{2}$ fluorine-doped tin oxide $\left(\mathrm{SnO}_{2}: \mathrm{F}\right)$ coated glass substrates with a native texture (Asahi U). Figure 1 schematically shows the tandem junction solar cell configuration used in the photovoltaic arrangement. For the investigation of the intrinsic a-Si:H layers alone, glass substrate (type Corning Eagle XG) and crystalline silicon wafers were used as substrates and all respective single aSi:H layers had a thickness of approximately $500 \mathrm{~nm}$. For the photoelectrochemical arrangement, $50 \mathrm{~nm}$ of platinum was deposited on the $\mathrm{ZnO} / \mathrm{Ag}$ back contact by electron beam evaporation.

2.2. Characterization of Materials and Solar Cells. Infrared (IR) absorption measurements were carried out, using a Fourier transform spectrometer (type Nicolet 5700), to evaluate the hydrogen content $c_{\mathrm{H}}$ in the intrinsic a-Si:H layer. IR transmission was measured between 400 and $2400 \mathrm{~cm}^{-1}$. This spectrum was normalized to the spectrum of the crystalline silicon wafer substrate.

Photothermal deflection spectroscopy (PDS) was performed to measure the absorption spectra of the intrinsic aSi:H layers, which were deposited on glass substrates. From these spectra the gap energy $E_{04}$ with a PDS absorption coefficient of $10^{4} \mathrm{~cm}^{-1}$ was extracted, which serves as a measure for the optical band gap of the intrinsic a-Si:H layer.

The constant photocurrent method (CPM) was used to evaluate the absorption within the band gap (e.g., subgap absorption), which can be linked to the defect density of the aSi:H material. The corresponding defect absorption densities 
of the a-Si:H intrinsic layers were determined by using the absorption coefficient $\alpha_{1.2}$ at an energy of $1.2 \mathrm{eV}$ [29].

Solar cells were characterized by current-voltage $(J-V)$ measurements under AM 1.5 illumination using a double source (Class A) sun simulator and by quantum efficiency $(\mathrm{QE})$ measurements.

2.3. Photoelectrochemical Measurements. The photoelectrochemical performance of the electrodes was evaluated at room temperature in an aqueous $0.1 \mathrm{M}$ sulfuric acid $\left(\mathrm{H}_{2} \mathrm{SO}_{4}\right)$ electrolyte solution $(\mathrm{pH} 1)$ using a three-electrode configuration [30]. The potential of the working electrode was controlled by a potentiostat ( $\mu$ Autolab Type III). For illumination, a $150 \mathrm{~W}$ xenon-halogen lamp was used, which was calibrated (by adjusting the current) with a crystalline silicon diode to provide a light intensity of $100 \mathrm{~mW} \mathrm{~cm}^{-2}$. The solar cells were illuminated through the glass substrate. The set-up of the electrochemical cell (type Zahner PECC-2) consists of a Teflon cell body and three electrodes: a working electrode (optimized a-Si:H/a-Si:H tandem junction solar cell, $8 \mathrm{~mm}$ diameter), a coiled platinum wire as a counter electrode, and a $\mathrm{Ag} / \mathrm{AgCl}$ reference electrode being in contact with $3 \mathrm{M}$ sodium chloride $(\mathrm{NaCl})[0.268 \mathrm{~V}$ versus normal hydrogen electrode (NHE)]. For simplicity, the entire set-up will be denoted as photoelectrochemical cell (PEC) arrangement hereafter. Cyclic voltammetry measurements were performed with a scan rate of $30 \mathrm{mV} \mathrm{s}^{-1}$. Electrical contact to the $\mathrm{SnO}_{2}$ coated substrate, that is, the front contact of the solar cell, was made by a silver paste.

\section{Results and Discussion}

3.1. Material Properties of Intrinsic a-Si:H Absorber Layer. Since the band gap of amorphous a-Si:H correlates with the hydrogen content of the material [22], FTIR measurements were conducted to estimate the amount of hydrogen in the samples. Figure 2 shows the hydrogen content as a function of the substrate temperature for a-Si:H layers with different silane concentrations. The general trend indicates that a decrease in $T_{s}$ results in an increase of $c_{\mathrm{H}}$. This behavior can be attributed to the increased desorption of hydrogen at higher substrate temperatures. As deposition temperature increases, the desorption of hydrogen atoms is energetically favored and thus less hydrogen is incorporated into the layer [31]. No clear dependency of $c_{\mathrm{H}}$ on the silane concentration in the chosen range was visible in FTIR data. The hydrogen content in all samples investigated is between $10.6 \%$ and $16.8 \%$.

For the determination of the band gap energy of the aSi:H material, absorption spectra for different $T_{s}$ and SC are measured and subsequently evaluated, with respect to $E_{04}$ as an estimation of the band gap. The evaluated $E_{04}$ values for all samples are shown in Figure 3. In the considered temperature range the band gap energy $E_{04}$ decreases by approximately $80 \mathrm{meV}$ with increasing $T_{s}$ for a given SC. Additionally, a slight dependency of the $E_{04}$ on SC can be extracted. For constant $T_{s}$, an average difference of approximately $30 \mathrm{meV}$ between SC of $4 \%$ and $10 \%$ was observed. Considering all

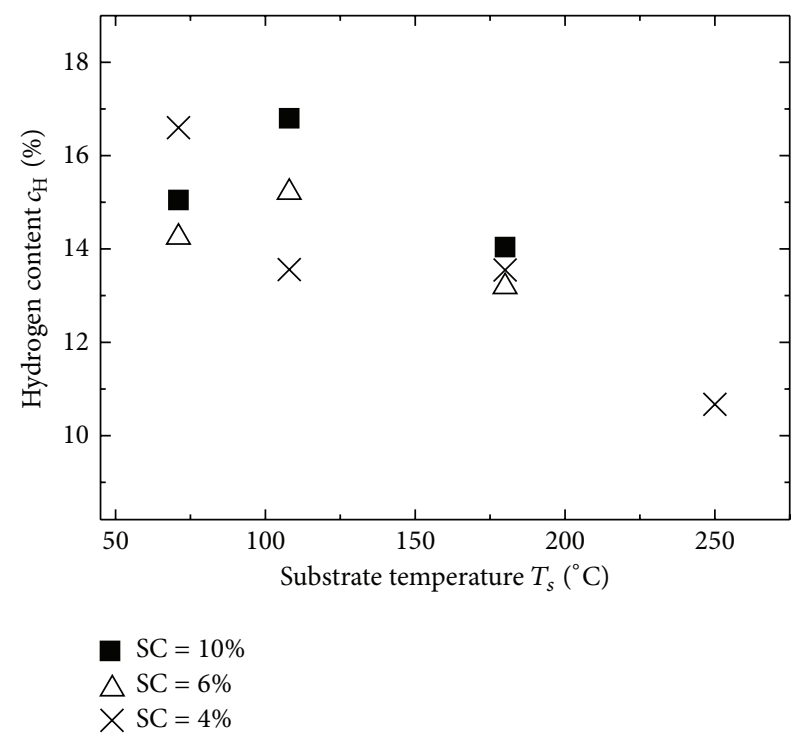

FIGURE 2: Hydrogen content as a function of the substrate temperature during deposition of the a-Si:H layers, with different silane concentrations.

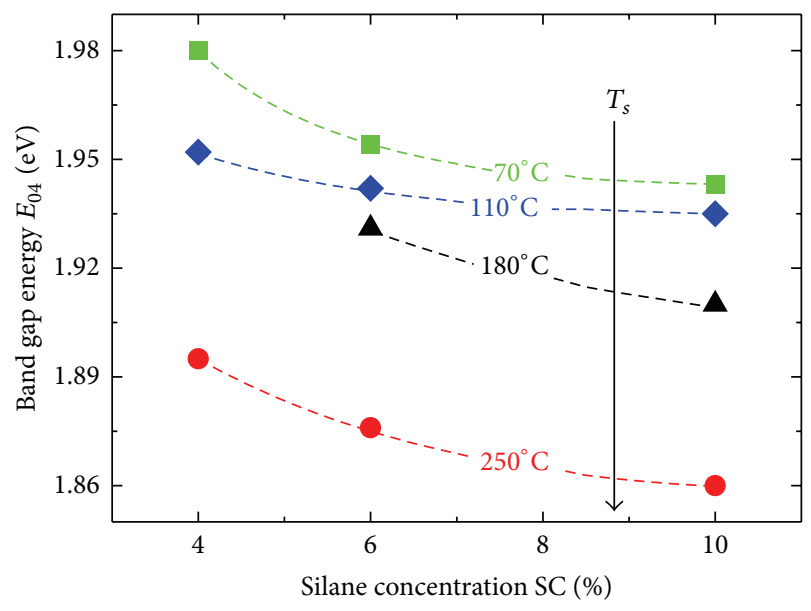

Figure 3: $E_{04}$ band gap as a function of silane concentrations for a-Si:H layers deposited at different substrate temperatures $T_{s}$. The dotted lines are to guide the eye.

a-Si:H absorber layers, the optical band gap could be varied by $120 \mathrm{meV}$ from $1.86 \mathrm{eV}$ to $1.98 \mathrm{eV}$.

Figure 4 presents the evaluated $E_{04}$ values as a function of $c_{\mathrm{H}}$ for different silane concentrations. The data of this study is in line with the commonly observed trend for an increase of the band gap energy with increasing fraction of bound hydrogen in the a-Si:H material [32-34]. A possible explanation suggested that the hydrogen could be involved in breaking of weak $\mathrm{Si}-\mathrm{Si}$ bonds responsible for the states in the top of the valence band. As a consequence, by increasing $c_{\mathrm{H}}$, stronger $\mathrm{Si}-\mathrm{H}$ bonds emerge, leading to states deep in the valence band and resulting in the valence band edge being shifted down. The conduction band remains unaffected and thus, the band gap energy increases [22, 32]. Other microscopic models involve a discussion of the effects of nanosized 


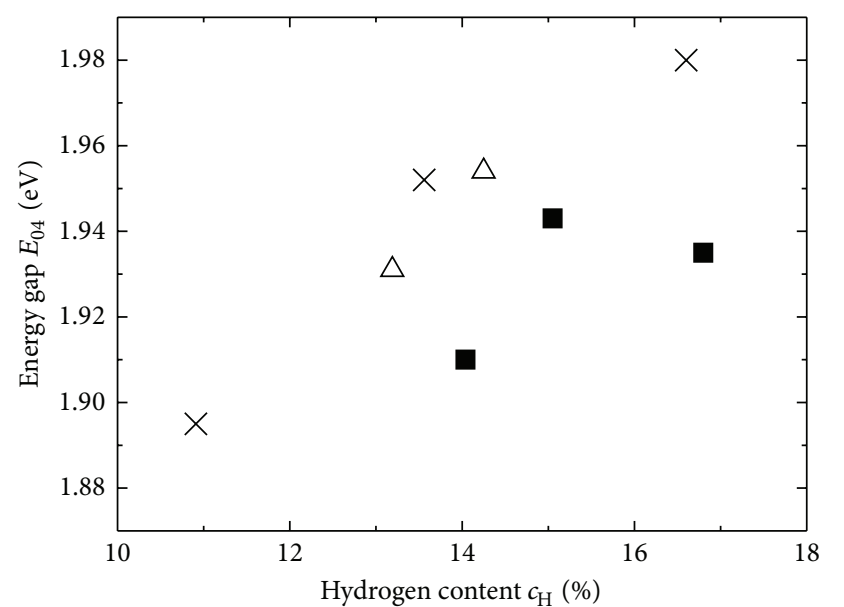

$$
\begin{aligned}
& S C=10 \% \\
\triangle S C & =6 \% \\
X S C & =4 \%
\end{aligned}
$$

FIGURE 4: Band gap energy $E_{04}$ as a function of the hydrogen content of deposited a-Si:H layers with different silane concentrations.

void configurations on the hydrogen incorporation in a-Si:H material $[35,36]$.

The defect density is an important parameter for absorber materials, because electronic defects can act as recombination centers and lead to a deterioration of the device performance $[37,38]$. In general, it is well accepted that a reduction in the deposition temperature (below $250^{\circ} \mathrm{C}$ ) results in the increase in the defect density of a-Si:H material [31]. Here, by adjusting SC together with $T_{s}$, we can maintain a material with a reasonable electronic quality (low defect density) even at a very low deposition temperature of around $70^{\circ} \mathrm{C}$. Figure 5 shows the absorption at an energy of $1.2 \mathrm{eV}$ as a function of $T_{s}$ for different SC of the a-Si:H layers. It is apparent that for substrate temperatures between $110^{\circ} \mathrm{C}$ and $250^{\circ} \mathrm{C}$ the absorption in the subgap region is similar for different silane concentrations investigated here and $\alpha_{1.2}$ ranges between $4.2 \mathrm{~cm}^{-1}$ and $8.5 \mathrm{~cm}^{-1}$. At a temperature of $70^{\circ} \mathrm{C}$, a distinct trend of decreasing $\alpha_{1.2}$ with decreasing silane concentration was observed. The defect absorption in this region rapidly increases up to $28 \mathrm{~cm}^{-1}$ for SC of $10 \%$. By reducing SC of the a-Si:H layers deposited at $70^{\circ} \mathrm{C}, \alpha_{1.2}$ continuously decreases to $6.5 \mathrm{~cm}^{-1}$ for SC of $4 \%$. This value is similar to $\alpha_{1.2}$ values of the layers deposited at higher temperatures. Hence, this result emphasizes that the electronic quality of the a-Si:H material deposited at low substrate temperatures (around $70^{\circ} \mathrm{C}$ ) can be improved, in terms of defect absorption density, by using lower silane concentrations during the deposition. We note that even at low SC of $4 \%$, the materials are still fully amorphous as evident from the Raman scattering experiments.

\subsection{Solar Cells}

3.2.1. Single Junction Solar Cells. The investigated intrinsic a-Si:H absorber layers with different band gaps were subsequently applied in single junction solar cells in a $\mathrm{p}-\mathrm{i}-\mathrm{n}$

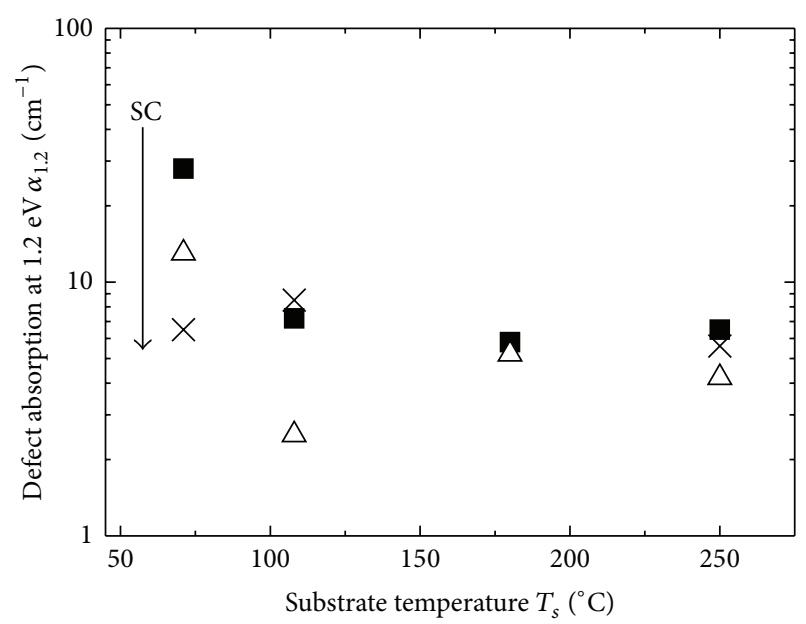

$$
\begin{aligned}
& S C=10 \% \\
\triangle S C & =6 \% \\
X S C & =4 \%
\end{aligned}
$$

Figure 5: Absorption coefficient at $1.2 \mathrm{eV}$ as a function of substrate temperature for different silane concentrations of the intrinsic aSi:H layer.

configuration. The solar cells were prepared with intrinsic a$\mathrm{Si}: \mathrm{H}$ layers at silane concentrations of $4 \%$ and $10 \%$, in order to consider the entire range of $E_{04}$ absorber layer band gaps (from $1.86 \mathrm{eV}$ to $1.98 \mathrm{eV}$ ) for the relevant temperatures, shown in Figure 3.

The performance of the a-Si:H solar cells as a function of $T_{s}$ is shown in Figure 6. Reducing $T_{s}$ from $250^{\circ} \mathrm{C}$ down to $110^{\circ} \mathrm{C}$, the open-circuit voltage $V_{\mathrm{OC}}$ increases with decreasing $T_{s}$ and can be varied from $802 \mathrm{mV}$ up to a value of $946 \mathrm{mV}$, achieved in the case of an absorber layer with SC of $4 \%$ and $T_{s}$ of $130^{\circ} \mathrm{C}$ (Figure $\left.6(\mathrm{~b})\right)$. In this temperature range $\left(250^{\circ} \mathrm{C}-\right.$ $110^{\circ} \mathrm{C}$ ), the fill factor FF is only slightly affected and varies between $68.5 \%$ and $73.8 \%$ for SC of $10 \%$ and between $70.2 \%$ and $74.2 \%$ for SC of $4 \%$ (Figure $6(\mathrm{c})$ ). The best efficiency $\eta$ of $10.3 \%$ is obtained with an intrinsic a-Si:H layer with SC of $10 \%$, deposited at $180^{\circ} \mathrm{C}$ (Figure $6(\mathrm{a})$ ).

For even lower $T_{s}$ of $70^{\circ} \mathrm{C}$ all performance parameters tend to deteriorate considerably, as compared with the solar cells deposited at $T_{s}$ of $110^{\circ} \mathrm{C}$ or above. In the $70^{\circ} \mathrm{C}$ temperature region increased defect absorption density $\alpha_{1.2}$ (Figure 5.) and higher optical band gap $E_{04}$ (Figure 3) significantly impair the electronic material quality. Nevertheless, as already apparent in the previous section, through the use of lower SC during low-temperature deposition, a significant improvement of the optoelectronic properties of $\mathrm{a}-\mathrm{Si}: \mathrm{H}$ material can be achieved. When SC is reduced down to $4 \%$, a significant improvement in $V_{\mathrm{OC}}$ and $\mathrm{FF}$ is observed in the case of solar cells deposited at temperatures below $180^{\circ} \mathrm{C}$. At $T_{s}$ of $70^{\circ} \mathrm{C}$ and SC of $4 \%$, all parameters are enhanced, compared to the $70^{\circ} \mathrm{C}$ cell with SC of $10 \%$, and $\eta$ yields $7.7 \%$ (Figure 6(a)). This underlines that a combination of low deposition temperature together with reduced SC of the absorber layer is necessary to obtain high voltage solar cells with appropriate efficiency level. 


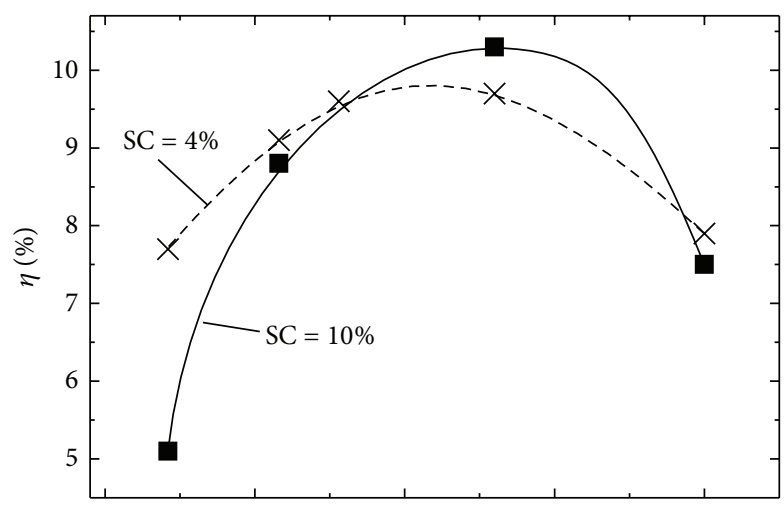

(a)

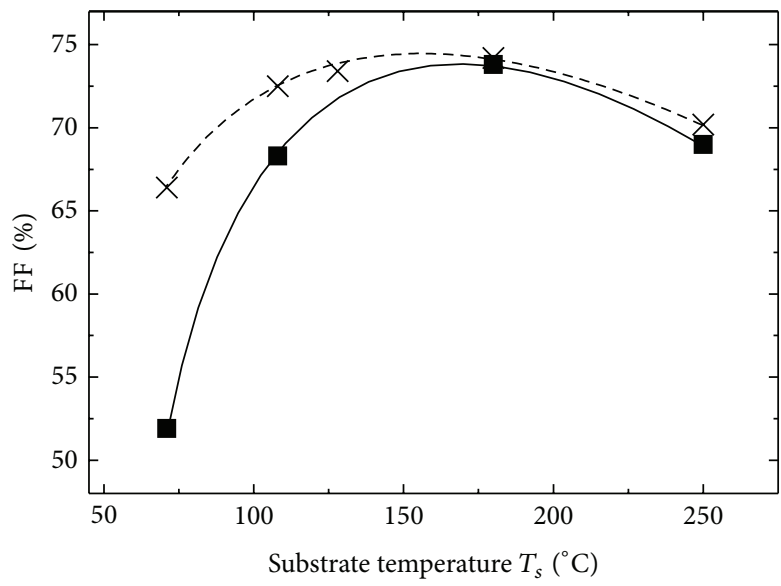

(c)

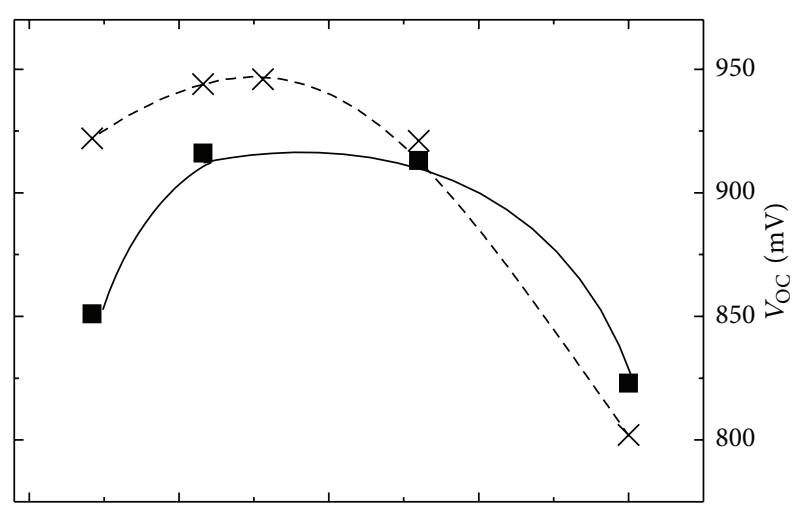

(b)

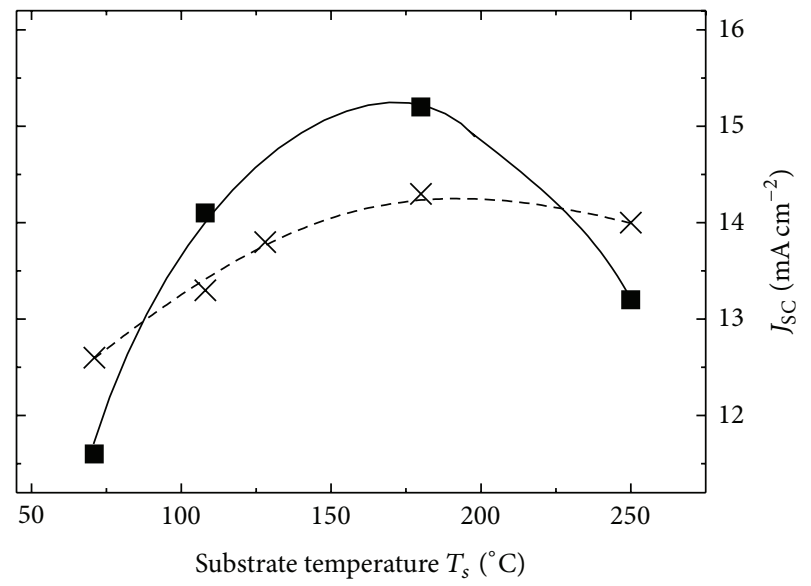

(d)

FIGURE 6: Photovoltaic parameters of single junction solar cells (efficiency (a), open-circuit voltage (b), fill factor (c), and short circuit current density (d)) as a function of the substrate temperature of the intrinsic a-Si:H layer, with $10 \%$ and $4 \%$ silane concentration, respectively. The lines are to guide the eye.

Figure $6(\mathrm{~d})$ presents the $J_{\mathrm{SC}}$ data of the solar cell series as a function of $T_{s}$. From $70^{\circ} \mathrm{C}$ to $180^{\circ} \mathrm{C}, J_{\mathrm{SC}}$ increases with increasing $T_{s}$ and, except for $T_{s}$ of $70^{\circ} \mathrm{C}$, solar cells with SC of $10 \%$ promote higher $J_{\mathrm{SC}}$ compared to cells with SC of $4 \%$. This can be explained by the wider $E_{04}$ gap of a-Si:H layers with SC of $4 \%$, in comparison to layers with SC of $10 \%$ (Figure 3). For $T_{s}$ of $250^{\circ} \mathrm{C}$ however, $J_{\mathrm{SC}}$ decreases for both SC.

The quantum efficiencies for the solar cell series (the same as in Figure 6) deposited at SC of $4 \%$ and $10 \%$ at different $T_{s}$ are shown in Figures 7(a) and 7(b), respectively. In the longer wavelength region the expected increase in QE with increasing $T_{s}$ (i.e., decreasing $E_{04}$ ) is apparent for both SC. The $\mathrm{QE}$ in the shorter wavelength region reflects the trend of $J_{\text {SC }}$ data shown in Figure $6(\mathrm{~d})$. Thus, the decrease in total $J_{\text {SC }}$ for $T_{s}$ of $250^{\circ} \mathrm{C}$ (Figure 6(d)) is caused by the drop in current under short wavelength illumination and can be localized to the region of the solar cell where light of short wavelengths is mainly absorbed, that is, the region of the p-doped/intrinsic a-Si:H layer interface. At $T_{s}$ of $250^{\circ} \mathrm{C}$ for the deposition of the intrinsic absorber layer, boron diffusion from the p-doped layer (deposited at $180^{\circ} \mathrm{C}$ ) into the intrinsic a-Si:H layer is assisted, leading to a deterioration of the $\mathrm{p}$-/i-interface, which can result in a reduction of the short wavelength QE [39]. In addition, as can be deduced from Figure 7(a), the QE for $T_{s}$ of $70^{\circ} \mathrm{C}$ deteriorates over the entire wavelength range at SC of $10 \%$ but can be improved considerably by using a lower SC of $4 \%$ during the deposition of the intrinsic a-Si:H layer (Figure 7(b)).

3.2.2. Tandem Junction Solar Cells. Several tandem junction combinations of two a-Si:H single junction solar cells have been realized. The top and bottom cell combinations along with the absorber layer parameters (SC and $T_{s}$ ) and photovoltaic device parameters are listed in Table 1 . The bottom cell thickness was $400 \mathrm{~nm}$ and the top cell thickness was $110 \mathrm{~nm}$, respectively, for all the tandem junction cells from Table 1.

The data in Table 1 confirms that a broad range of high open-circuit voltages can be achieved, ranging from $1601 \mathrm{mV}$ to $1870 \mathrm{mV}$. In addition, the $V_{\mathrm{OC}}$ values of the tandem solar cells are in good agreement with the summed $V_{\mathrm{OC}}$ values of the respective individual subcells, proving a stable process control. To ensure efficient hydrogen production, the a$\mathrm{Si}: \mathrm{H} / \mathrm{a}-\mathrm{Si}: \mathrm{H}$ photocathode should preferably provide high photocurrent and operate near its maximum power point (MPP) during photoelectrochemical water splitting. Thus, $J_{\mathrm{SC}}$ and $V_{\mathrm{MPP}}$ play an important role here. In this regard, the 


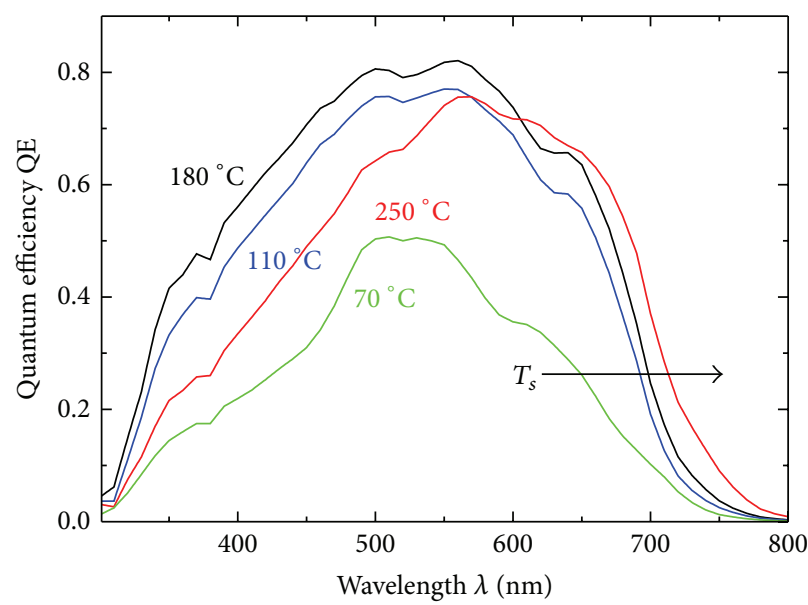

(a)

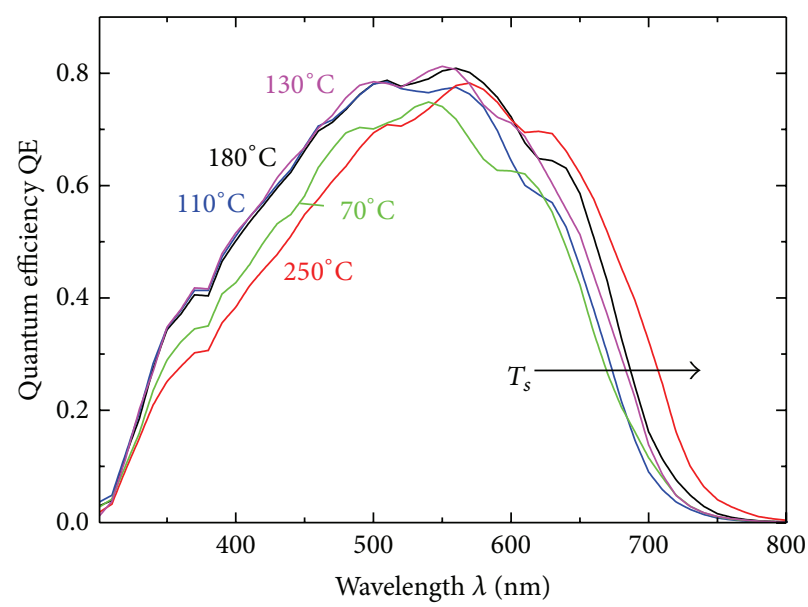

(b)

Figure 7: Quantum efficiency curves for single junction solar cells at silane concentration of (a) $10 \%$ and (b) $4 \%$ for different $T_{s}$ of the absorber layer.

TABle 1: Photovoltaic parameters of a-Si:H/a-Si:H tandem junction solar cells fabricated with varying SC and $T_{s}$ of top and bottom cell.

\begin{tabular}{|c|c|c|c|c|c|c|c|c|}
\hline \multicolumn{2}{|c|}{ Top cell } & \multicolumn{2}{|c|}{ Bottom cell } & \multirow[b]{2}{*}{$\eta[\%]$} & \multirow[b]{2}{*}{$V_{\mathrm{OC}}[\mathrm{mV}]$} & \multirow[b]{2}{*}{$\mathrm{FF}[\%]$} & \multirow[b]{2}{*}{$J_{\mathrm{SC}}\left[\mathrm{mA} / \mathrm{cm}^{2}\right]$} & \multirow[b]{2}{*}{$V_{\mathrm{MPP}}[\mathrm{mV}]$} \\
\hline $\mathrm{SC}_{\text {top }}[\%]$ & $T_{s, \text { top }}\left[{ }^{\circ} \mathrm{C}\right]$ & $\mathrm{SC}_{\text {bot }}[\%]$ & $T_{s, \text { bot }}\left[{ }^{\circ} \mathrm{C}\right]$ & & & & & \\
\hline 4 & 250 & 4 & 250 & 8.3 & 1602 & 71.8 & 7.2 & 1325 \\
\hline 10 & 180 & 4 & 250 & 8.7 & 1700 & 68.5 & 7.4 & 1410 \\
\hline 4 & 110 & 4 & 110 & 9.5 & 1870 & 77.5 & 6.6 & 1580 \\
\hline 10 & 180 & 10 & 180 & 9.8 & 1796 & 78.8 & 7 & 1555 \\
\hline 4 & 130 & 10 & 180 & 10.5 & 1816 & 73.5 & 7.9 & 1520 \\
\hline 4 & 130 & 4 & 130 & 9.7 & 1855 & 78.2 & 6.7 & 1595 \\
\hline
\end{tabular}

best two tandem cells listed in Table 1 , with respect to $J_{\mathrm{SC}}$ and $V_{\text {MPP }}$, were chosen to be further optimized by means of current matching. The MPP voltage for all tandem cells is presented in the last column of Table 1. The highest $V_{\text {MPP }}$ of $1595 \mathrm{mV}$ is achieved by the tandem cell combining two subcells with SC of $4 \%$ and both $T_{s \text {,top }}$ and $T_{s \text {, bot }}$ of $130^{\circ} \mathrm{C}$. The tandem cell consisting of a $4 \% \mathrm{SC}$ top cell with $T_{\text {s,top }}$ of $130^{\circ} \mathrm{C}$ and a $10 \%$ SC bottom cell with $T_{s, \text { bot }}$ of $180^{\circ} \mathrm{C}$ exhibits the highest $J_{\mathrm{SC}}$ of $7.9 \mathrm{~mA} / \mathrm{cm}^{2}$ and an $\eta$ of $10.5 \%$.

In order to match the two subcells, with respect to the current, the thickness of the absorber layer of the top cell $d_{\text {top }}$ has been optimized. The two chosen tandem cells were deposited with $d_{\text {top }}$ of $70 \mathrm{~nm}$ and $90 \mathrm{~nm}$, respectively, and compared with the tandem cell comprising the $110 \mathrm{~nm}$ thick top cell. Figure 8 presents the respective photovoltaic parameters as a function of the top cell thickness.

The matching series of the tandem cells with top and bottom absorber layers deposited at different $T_{s}$ and SC (filled squares in Figure 8 ) shows that $V_{\mathrm{OC}}$ was only marginally affected by a reduced top cell thickness and increased by $15 \mathrm{mV}$ for $d_{\text {top }}$ of $110 \mathrm{~nm}$ to $70 \mathrm{~nm}$ (Figure 8(b)). The $J_{\text {SC }}$ decreased with decreasing $d_{\text {top }}$ from $7.9 \mathrm{~mA} / \mathrm{cm}^{2}$ for $d_{\text {top }}$ of $110 \mathrm{~nm}$ to $6.7 \mathrm{~mA} / \mathrm{cm}^{2}$ for $d_{\text {top }}$ of $70 \mathrm{~nm}$ (Figure $8(\mathrm{~d})$ ). As current matching should enhance the $J_{\text {SC }}$ [40], one can conclude that the tandem cell was better matched at $d_{\text {top }}$ of
$110 \mathrm{~nm}$ and became top cell limited by further reducing $d_{\text {top }}$. The fill factor is expected to decrease when top and bottom cells are matched [39]. This is observed in Figure 8(c) where FF decreased by $4.9 \%$ with increasing $d_{\text {top }}$. The highest $\eta$ of $10.5 \%$ was achieved when bottom and top cell are current matched (Figure 8(a)).

In the matching series of the second tandem cell, in which both top and bottom cell were deposited at $T_{s}$ of $130^{\circ} \mathrm{C}$ and SC of $4 \%$ (open squares in Figure 8 ), the reduction of $d_{\text {top }}$ leads to an increase in $J_{\mathrm{SC}}$ of $0.4 \mathrm{~mA} / \mathrm{cm}^{2}$ from $d_{\text {top }}$ of $110 \mathrm{~nm}$ to $70 \mathrm{~nm}$ (Figure $8(\mathrm{~d})$ ). The FF decreased by $2.6 \%$ with decreasing $d_{\text {top }}$ (Figure $8(\mathrm{c})$ ). The highest $V_{\mathrm{OC}}$ of $1871 \mathrm{mV}$ was achieved for the tandem cell with $d_{\text {top }}$ of $90 \mathrm{~nm}$ (Figure $8(\mathrm{~b})$ ), which also exhibits the highest $\eta$ of $9.9 \%$.

The best two tandem cells, with respect to $\eta$, are summarized in Table 2.

3.3. Photoelectrochemical Measurements. The performance of the developed a-Si:H/a-Si:H tandem junction based photocathodes was examined and compared to the photovoltaic performance of the corresponding solar cells. For this purpose, four tandem cells covering up the $V_{\text {OC }}$ range from $1600 \mathrm{mV}$ to $1870 \mathrm{mV}$ (from Tables 1 and 2) were chosen and the onset potential for cathodic current $\left(E_{\text {onset }}\right)$, the potential at maximum power point $\left(E_{\mathrm{MPP}}\right)$, and the photocurrent density at $0 \mathrm{~V}$ versus $\mathrm{RHE}\left(J_{\mathrm{RHE}}\right)$ were determined. Table 3 


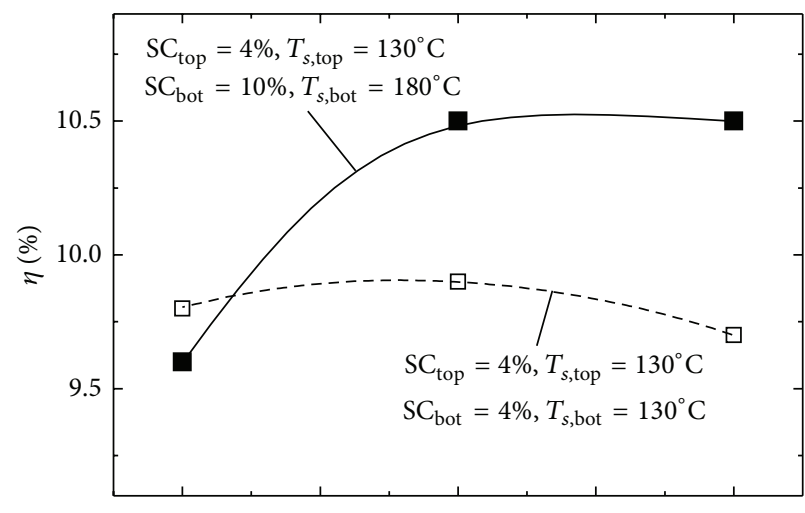

(a)

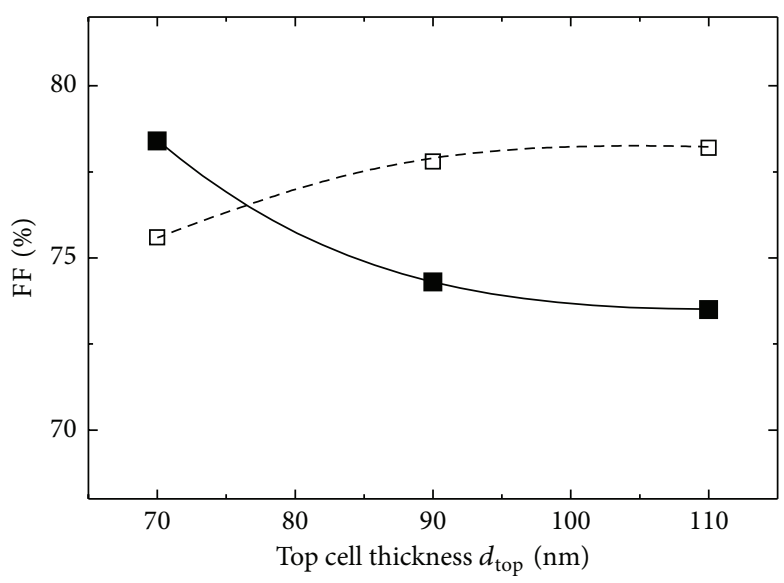

(c)

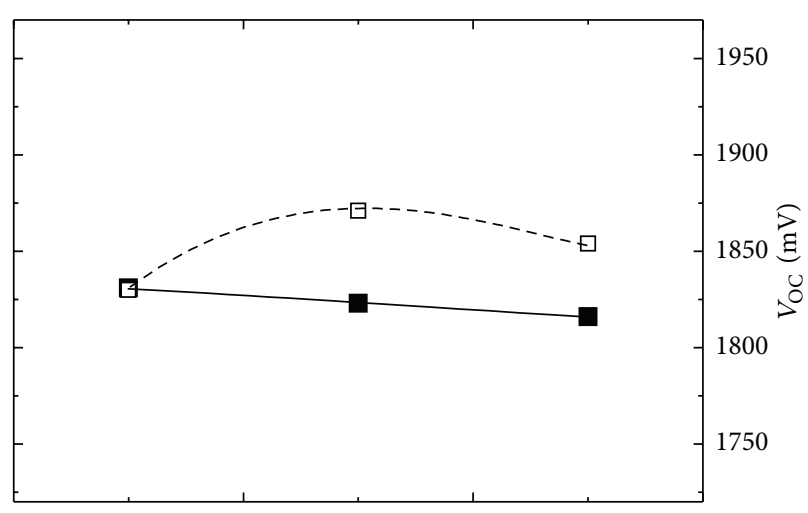

(b)

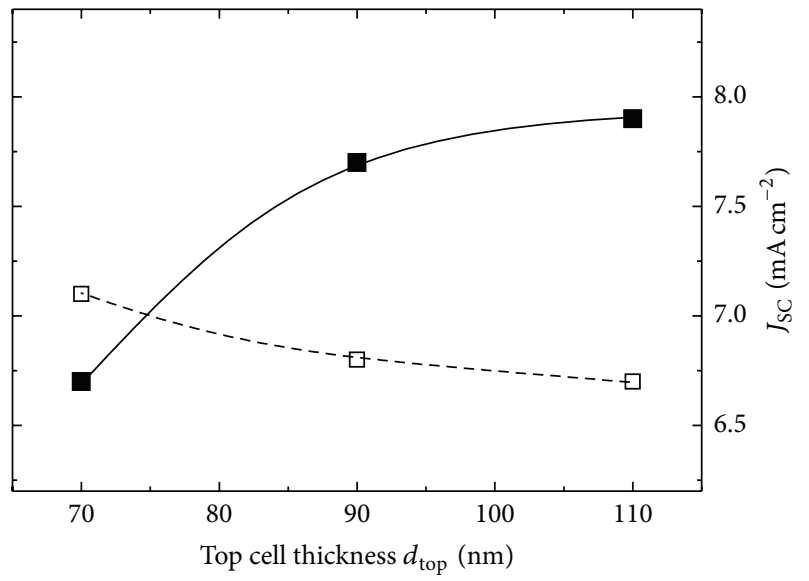

(d)

FIGURE 8: Photovoltaic parameters of the current matching series of two tandem junction solar cells deposited at different SC and $T_{s}$, as a function of their top cell thickness. The lines are to guide the eye.

TABLE 2: Photovoltaic parameters of a-Si:H/a-Si:H tandem junction solar cells resulting from the current matching series.

\begin{tabular}{ccccccccc}
\hline \multicolumn{2}{c}{ Top cell } & \multicolumn{2}{c}{ Bottom cell } \\
$\mathrm{SC}_{\text {top }}[\%]$ & $T_{s, \text { top }}\left[{ }^{\circ} \mathrm{C}\right]$ & $\mathrm{SC}_{\text {bot }}[\%]$ & $T_{s, \text { bot }}\left[{ }^{\circ} \mathrm{C}\right]$ & $\eta[\%]$ & $V_{\mathrm{OC}}[\mathrm{mV}]$ & $\mathrm{FF}[\%]$ & $J_{\mathrm{SC}}\left[\mathrm{mA} / \mathrm{cm}^{2}\right]$ & $V_{\mathrm{MPP}}[\mathrm{mV}]$ \\
\hline 4 & 130 & 10 & 180 & 10.5 & 1816 & 73.5 & 7.9 & 1520 \\
4 & 130 & 4 & 130 & 9.9 & 1872 & 77.8 & 6.8 \\
\hline
\end{tabular}

provides the photovoltaic and PEC device parameters of the respective photocathodes. $E_{\mathrm{MPP}}$ and $J_{\mathrm{RHE}}$ (from Table 3.) are extracted from cyclic voltammetry $(\mathrm{CV})$ measurements depicted in Figure 9. The measurements were conducted with the four a-Si:H/a-Si:H photocathodes without any further surface or back contact modification.

The disparity in $J_{\mathrm{SC}}$ and $J_{\mathrm{RHE}}$ values originates from the different illumination source used in photovoltaic and PEC arrangement, respectively. AM 1.5 illumination provides higher light intensities in the wavelength range between $300 \mathrm{~nm}$ and $800 \mathrm{~nm}$, where a-Si:H possesses the highest light absorption, compared to the halogen lamp used in the PEC arrangement. Notwithstanding this, photovoltaic and photoelectrochemical performances show the same trends. The higher the $V_{\text {MPP }}$ of a photocathode is, the higher its $E_{\mathrm{MPP}}$ is. A similar correlation was observed for the current densities $J_{\mathrm{SC}}$ and $J_{\mathrm{RHE}}$. This result provides evidence that the photoelectrochemical performance of the photocathode can be partly deduced from the photovoltaic performance of the solar cell, which is highly important for further development.

Photocathode D exhibits the highest photocurrent density of $6.3 \mathrm{~mA} / \mathrm{cm}^{2}$ at $0 \mathrm{~V}$ versus RHE. $E_{\mathrm{MPP}}$ of photocathode $\mathrm{D}$ is $1098 \mathrm{mV}$ versus RHE and thus slightly lower than the highest $E_{\text {MPP }}$ value of $1127 \mathrm{mV}$ versus RHE and is promoted by photocathode $\mathrm{C}$, which in contrast has a lower $J_{\mathrm{RHE}}$ of $5.3 \mathrm{~mA} / \mathrm{cm}^{2}$. The onset potential of cathodic current was taken as the value at a photocurrent density of $-0.5 \mathrm{~mA} / \mathrm{cm}^{2}$. Hereby, $E_{\text {onset }}$ data (from Table 3 ) reflects $V_{\text {OC }}$ data obtained in photovoltaic arrangement and shifts anodically from photocathodes A and B (1196 mV versus RHE and $1338 \mathrm{mV}$ versus RHE, resp.) to photocathodes D and C $(1450 \mathrm{mV}$ versus RHE and $1495 \mathrm{mV}$ versus RHE, resp.). Efficient selfcontained solar water splitting requires a photocathode with high photocurrent at a positive potential over $1.23 \mathrm{~V}$ versus 
TABLE 3: Photovoltaic and PEC parameters of a-Si:H/a-Si:H tandem junction based photocathodes.

\begin{tabular}{lcccccccc}
\hline Photocathode $\eta[\%]$ & $V_{\mathrm{OC}}[\mathrm{mV}]$ & $\mathrm{FF}[\%]$ & $J_{\mathrm{SC}}\left[\mathrm{mA} / \mathrm{cm}^{2}\right]$ & $V_{\mathrm{MPP}}[\mathrm{mV}]$ & $E_{\text {onset }}[\mathrm{mV}$ versus RHE $]$ & $E_{\mathrm{MPP}}[\mathrm{mV}$ versus RHE $]$ & $J_{\mathrm{RHE}}\left[\mathrm{mA} / \mathrm{cm}^{2}\right]$ \\
\hline A & 8.3 & 1602 & 71.8 & 7.2 & 1325 & 1196 & 832 & 5.9 \\
B & 8.7 & 1700 & 68.5 & 7.4 & 1410 & 1338 & 960 & 6.1 \\
C & 9.9 & 1872 & 77.8 & 6.8 & 1600 & 1495 & 1127 & 1098 \\
D & 10.5 & 1816 & 73.5 & 7.9 & 1520 & 1450 & 5.3 \\
\hline
\end{tabular}

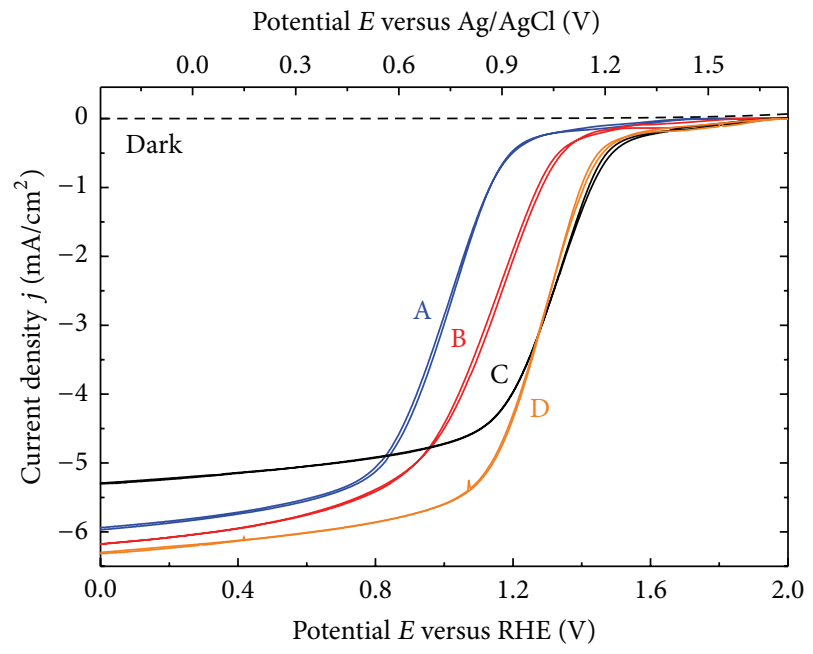

FIGURE 9: Cyclic voltammetry measurement of a-Si:H/a-Si:H photocathodes (listed in Table 3). Measurements were performed in $0.1 \mathrm{M}$ $\mathrm{H}_{2} \mathrm{SO}_{4}$ solution ( $\mathrm{pH}$ ) under $100 \mathrm{~mW} / \mathrm{cm}^{2}$ illumination intensity at a scan rate of $30 \mathrm{mV} \mathrm{s}^{-1}$. The dark current is shown as a black dashed curve.

RHE [13]. Thus, within this study photocathodes C and D are the most suitable candidates for PEC water splitting devices.

To describe the effect of different back contact catalysts, photocathode $\mathrm{C}$ was further investigated, as it exhibits the highest $E_{\text {onset }}$. Figure 10 shows the cyclic voltammograms measured for a-Si:H/a-Si:H photocathodes with no metallic back contact (solid grey curve, silicon in contact to the electrolyte), with $\mathrm{ZnO} / \mathrm{Ag}$ back contact (solid black curve, photocathode $\mathrm{C}$ from Table 3) and with $\mathrm{ZnO} / \mathrm{Ag} / \mathrm{Pt}$ back contact (dashed curve). The low photocurrent $\left(3.1 \mathrm{~mA} / \mathrm{cm}^{2}\right.$ at $0 \mathrm{~V}$ versus $\mathrm{RHE}$ ) of the back contact-free photocathode is caused by optical losses, due to the missing metallic backreflector. Additionally, the injection of charge carriers into the electrolyte is kinetically limited for metal-free surfaces, resulting in high overpotentials for water reduction [24]. This is confirmed by the significant shift of $E_{\text {onset }}$ in negative bias direction ( $950 \mathrm{mV}$ versus RHE). Unlike the photocathodes with metallic back contacts, forward and reverse scan of the bare a-Si:H/a-Si:H photocathode are shifted, revealing a protective or passivation effect of the metallic back contact [12]. No effect on $J_{\text {RHE }}$ is observed when a thin $50 \mathrm{~nm}$ layer of platinum is deposited on the $\mathrm{ZnO} / \mathrm{Ag}$ back contact. Both photocathodes with metallic back contact provide $5.3 \mathrm{~mA} / \mathrm{cm}^{2}$ at $0 \mathrm{~V}$ versus $\mathrm{RHE}$, proving that the optics of the photocathode remains mainly unaffected by the platinum layer.

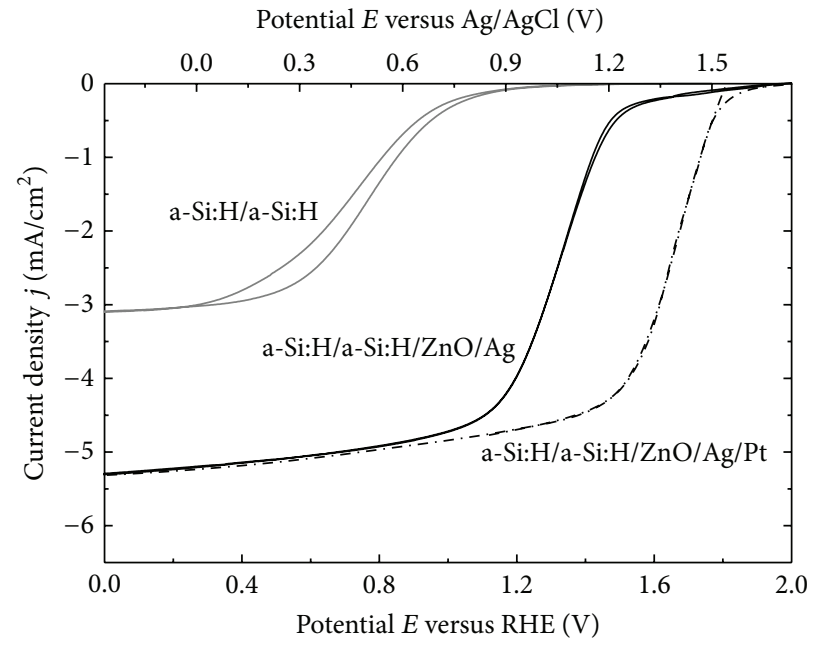

FIGURE 10: Cyclic voltammetry measurement of a-Si:H/a-Si:H photocathodes with no metallic back contact (solid grey curve), with $\mathrm{ZnO} / \mathrm{Ag}$ back contact (solid black curve, photocathode $\mathrm{C}$ from Table 3) and with $\mathrm{ZnO} / \mathrm{Ag} / \mathrm{Pt}$ back contact (dashed curve), in $0.1 \mathrm{M}$ $\mathrm{H}_{2} \mathrm{SO}_{4}$ solution ( $\mathrm{pH}$ ) under $100 \mathrm{~mW} / \mathrm{cm}^{2}$ illumination intensity at a scan rate of $30 \mathrm{mV} \mathrm{s}^{-1}$.

However, with respect to the $\mathrm{ZnO} / \mathrm{Ag}$ back contact photocathode, the photocathode with $\mathrm{ZnO} / \mathrm{Ag} / \mathrm{Pt}$ back contact shows a significant shift in $E_{\text {onset }}$ in positive bias direction $(270 \mathrm{mV})$ and is measured to be $1765 \mathrm{mV}$ versus RHE. Furthermore, an impressively high $E_{\mathrm{MPP}}$ of $1457 \mathrm{mV}$ versus RHE is exhibited by the platinized photocathode, with a photocurrent density of $4.4 \mathrm{~mA} / \mathrm{cm}^{2}$, which accentuates both, the excellent catalytic activity of platinum as a catalyst for the hydrogen evolution reaction (HER) and its viable combination with the a-Si:H/a-Si:H/ZnO/Ag tandem device. In fact, the photocurrent density of $4.4 \mathrm{~mA} / \mathrm{cm}^{2}$ at $1457 \mathrm{mV}$ versus RHE is the highest reported value at such positive potentials for a-Si:H single and tandem solar cell based photoelectrodes [13, 41-43]. Photocathodes, which can provide high photocurrents at more positive potentials, could effectively attenuate the catalytic activity requirement (i.e., reduction of overpotential losses) of the anode in a twoelectrode PEC system. Taking additionally into account the nonideal illumination of the a-Si:H/a-Si:H photocathode by the halogen lamp, our result a fortiori demonstrates the capability for a direct application of the developed photocathodes in efficient and self-contained PEC devices. A prior study on amorphous tandem junction solar cell used as photocathode reported $E_{\text {onset }}$ values of $1.35 \mathrm{~V}$ versus the saturated calomel electrode (SCE) along with a photocurrent 
density of $2 \mathrm{~mA} / \mathrm{cm}^{2}$ at $0 \mathrm{~V}$ versus SCE [41]. A similar approach led to $1.43 \mathrm{~V}$ versus $\mathrm{SCE}$ and $3 \mathrm{~mA} / \mathrm{cm}^{2}$ at $0 \mathrm{~V}$ versus SCE [42]. Furthermore, this study reported on a tandem junction a-Si:H solar cell deposited on a crystalline silicon wafer. This triple cell concept promoted a high $E_{\text {onset }}$ of $1.84 \mathrm{~V}$ versus RHE, but a rather low photocurrent density of $2.4 \mathrm{~mA} / \mathrm{cm}^{2}$. The most recent work focusing on the direct application of a-Si:H solar cells as photoelectrodes was done by Lin et al. [13]. Here, single junction a-Si:H solar cells were tested as photocathodes under the irradiation by a simulated sunlight (AM 1.5 light spectrum, $100 \mathrm{~mW} / \mathrm{cm}^{2}$ ) and exhibited an $E_{\text {onset }}$ of $0.93 \mathrm{~V}$ versus RHE and photocurrent densities of 6.1 and $9.4 \mathrm{~mA} / \mathrm{cm}^{2}$ at 0.8 and $0.7 \mathrm{~V}$ versus RHE, respectively.

As integrated water splitting devices require chemicalresistant electrodes, stability issues of the silicon solar cells in contact with aqueous solutions need to be addressed and are currently under investigation. Furthermore, light induced degradation plays a major role for a-Si:H based devices and has been extensively investigated [18, 43]. In the present study this was not yet a focus of our work. It should however be noticed that the important parameter $V_{\mathrm{OC}}$ is typically the least affected parameter upon prolonged illumination and in some cases even increases [44].

\section{Conclusion}

We presented the development of a-Si:H/a-Si:H based photocathodes for efficient hydrogen production. By varying the substrate temperature and $\mathrm{SiH}_{4}$ to total gas-flow concentration during the deposition of intrinsic a-Si:H absorber layers, we demonstrated that, in the case of a-Si:H/a-Si:H tandem cells, the optical and electrical properties of the a$\mathrm{Si}: H$ subcells can be tuned and provide an extended $V_{\mathrm{OC}}$ range in tandem devices. It was found that the $V_{\mathrm{OC}}$ of tandem solar cells, with efficiencies around $10 \%$, could systematically be adjusted between $1600 \mathrm{mV}$ and $1870 \mathrm{mV}$.

Furthermore, the performance of the developed tandem junction solar cells as photocathodes was demonstrated in a PEC arrangement. In particular, a-Si:H/a-Si:H photocathodes with $\mathrm{ZnO} / \mathrm{Ag} / \mathrm{Pt}$ back contact exhibited excellent onset potentials over $1760 \mathrm{mV}$ versus RHE with a photocurrent density of $5.3 \mathrm{~mA} / \mathrm{cm}^{2}$ at $0 \mathrm{~V}$ versus RHE and thus fulfill the main thermodynamic requirements to generate $\mathrm{H}_{2}$. The presented approach exploits a strategy of an efficient and lowcost route to solar hydrogen production based on amorphous thin film silicon tandem junction solar cells at a level which is sufficient for technological use.

\section{Conflict of Interests}

The authors declare that there is no conflict of interests regarding the publication of this paper.

\section{Acknowledgments}

The authors thank J. Klomfaß, S. Tillmanns, L. Petter, W. Reetz, H. Siekmann, U. Gerhards, O. Thimm, and W. Beyer for their contributions to this work. The research is partly financially supported by the Deutsche Forschungsgemeinschaft (DFG) Prority Programme 1613: Regeneratively Produced Fuels by Light Driven Water Splitting: Investigation of Involved Elementary Processes and Perspectives of Technologic Implementation and by the Bundesministerium für Bildung und Forschung (BMBF) in the network project: Sustainable Hydrogen (FKZ 03X3581B). J. Ziegler, B. Kaiser, and W. Jaegermann acknowledge partial financial support by the DFG Excellency Graduate School of Energy Science and Engineering (GSC 1070).

\section{References}

[1] N. S. Lewis and D. G. Nocera, "Powering the planet: chemical challenges in solar energy utilization," Proceedings of the National Academy of Sciences of the United States of America, vol. 103, no. 43, pp. 15729-15735, 2006.

[2] J. P. Holdren, "Energy and sustainability," Science, vol. 315, no. 5813, p. 737, 2007.

[3] O. Khaselev and J. A. Turner, "A monolithic photovoltaicphotoelectrochemical device for hydrogen production via water splitting," Science, vol. 280, no. 5362, pp. 425-427, 1998.

[4] T. G. Deutsch, C. A. Koval, and J. A. Turner, "III-V nitride epilayers for photoelectrochemical water splitting: GaPN and GaAsPN," The Journal of Physical Chemistry B, vol. 110, no. 50, pp. 25297-25307, 2006.

[5] A. Heller and R. G. Vadimsky, "Efficient solar to chemical conversion: $12 \%$ efficient photoassisted electrolysis in the [ptype $\operatorname{InP}(\mathrm{Ru})] / \mathrm{HCl}-\mathrm{KCl} / \mathrm{Pt}(\mathrm{Rh})$ cell," Physical Review Letters, vol. 46, no. 17, pp. 1153-1156, 1981.

[6] J. Ziegler, D. Fertig, B. Kaiser et al., "Preparation and characterization of GaP semiconductor electrodes for photoelectrochemical water splitting," Energy Procedia, vol. 22, pp. 108-113, 2012.

[7] A. Paracchino, V. Laporte, K. Sivula, M. Grätzel, and E. Thimsen, "Highly active oxide photocathode for photoelectrochemical water reduction," Nature Materials, vol. 10, no. 6, pp. 456-461, 2011.

[8] J. Y. Kim, G. Magesh, D. H. Youn et al., "Single-crystalline, wormlike hematite photoanodes for efficient solar water splitting," Nature, vol. 3, p. 2681, 2013.

[9] F. F. Abdi, L. Han, A. H. M. Smets, M. Zeman, B. Dam, and R. van de Krol, "Efficient solar water splitting by enhanced charge separation in a bismuth vanadate-silicon tandem photoelectrode," Nature Communications, vol. 4, article 3195, 2013.

[10] D. V. Esposito, I. Levin, T. P. Moffat, and A. A. Talin, " $\mathrm{H}_{2}$ evolution at Si-based metal-insulator-semiconductor photoelectrodes enhanced by inversion channel charge collection and H spillover," Nature Materials, vol. 12, no. 6, pp. 562-568, 2013.

[11] J. R. McKone, E. L. Warren, M. J. Bierman et al., "Evaluation of Pt, Ni, and Ni-Mo electrocatalysts for hydrogen evolution on crystalline Si electrodes," Energy and Environmental Science, vol. 4, no. 9, pp. 3573-3583, 2011.

[12] U. Sim, T.-Y. Yang, J. Moon et al., "N-doped monolayer graphene catalyst on silicon photocathode for hydrogen production," Energy \& Environmental Science, vol. 6, no. 12, pp. 3658-3664, 2013.

[13] Y. Lin, C. Battaglia, M. Boccard et al., "Amorphous Si thin film based photocathodes with high photovoltage for efficient hydrogen production," Nano Letters, vol. 13, no. 11, pp. 56155618, 2013. 
[14] L. Han, F. F. Abdi, P. Perez Rodriguez et al., "Optimization of amorphous silicon double junction solar cells for an efficient photoelectrochemical water splitting device based on a bismuth vanadate photoanode," Physical Chemistry Chemical Physics, vol. 16, no. 9, pp. 4220-4229, 2014.

[15] S. Y. Reece, J. A. Hamel, K. Sung et al., "Wireless solar water splitting using silicon-based semiconductors and earthabundant catalysts," Science, vol. 334, no. 6056, pp. 645-648, 2011.

[16] E. L. Miller, R. E. Rocheleau, and S. Khan, "A hybrid multijunction photoelectrode for hydrogen production fabricated with amorphous silicon/germanium and iron oxide thin films," International Journal of Hydrogen Energy, vol. 29, no. 9, pp. 907914, 2004.

[17] A. Shah, Thin-Film Silicon Solar Cells, Photovoltaics and LargeArea Electronics, CRC Press, 2008.

[18] B. Rech and H. Wagner, "Potential of amorphous silicon for solar cells," Applied Physics A, vol. 69, no. 2, pp. 155-167, 1999.

[19] J. R. Bolton, S. J. Strickler, and J. S. Connolly, "Limiting and realizable efficiencies of solar photolysis of water," Nature, vol. 316, no. 6028, pp. 495-500, 1985.

[20] M. F. Weber and M. J. Dignam, "Splitting water with semiconducting photoelectrodes-efficiency considerations," International Journal of Hydrogen Energy, vol. 11, no. 4, pp. 225-232, 1986.

[21] A. J. Nozik, "Photoelectrochemistry: applications to solar energy conversion," Annual Review of Physical Chemistry, vol. 29, pp. 189-222, 1978.

[22] L. Ley, "Photoemission and optical properties," Topics in Applied Physics, vol. 56, pp. 61-168, 2005.

[23] W. Beyer and H. Wagner, "The role of hydrogen in a-Si:Hresults of evolution and annealing studies," Journal of NonCrystalline Solids, vol. 59-60, no. 1, pp. 161-168, 1983.

[24] M. G. Walter, E. L. Warren, J. R. McKone et al., "Solar water splitting cells," Chemical Reviews, vol. 110, no. 11, pp. 6446-6473, 2010.

[25] R. van de Krol and M. Grätzel, Photoelectrochemical Hydrogen Production, Springer, New York, NY, USA, 2012.

[26] D. E. Carlson and C. R. Wronski, "Amorphous silicon solar cell," Applied Physics Letters, vol. 28, no. 11, pp. 671-673, 1976.

[27] S. Guha, J. Yang, P. Nath, and M. Hack, "Enhancement of open circuit voltage in high efficiency amorphous silicon alloy solar cells," Applied Physics Letters, vol. 49, no. 4, pp. 218-219, 1986.

[28] W. Böttler, V. Smirnov, J. Hüpkes, and F. Finger, “Texture-etched $\mathrm{ZnO}$ as a versatile base for optical back reflectors with welldesigned surface morphologies for application in thin film solar cells," Physica Status Solidi (A), vol. 209, no. 6, pp. 1144-1149, 2012.

[29] N. Wyrsch, F. Finger, T. J. McMahon, and M. Vanecek, "How to reach more precise interpretation of subgap absorption spectra in terms of deep defect density in a-Si:H," Journal of NonCrystalline Solids, vol. 137-138, part 1, pp. 347-350, 1991.

[30] G. Hodes, "Photoelectrochemical cell measurements: getting the basics right," Journal of Physical Chemistry Letters, vol. 3, no. 9, pp. 1208-1213, 2012.

[31] G. Ganguly and A. Matsuda, "Importance of surface processes in defect formation in a-Si:H," Journal of Non-Crystalline Solids, vol. 164-166, part 1, pp. 31-36, 1993.

[32] R. A. Street, Hydrogenated Amorphous Silicon, Cambridge Solid State Science Series, Cambridge University Press, Cambridge, UK, 1991.
[33] Y. Ashida, "Conference record of the 24th IEEE photovoltaic specialists conference," in Proceedings of the IEEE 1st World Conference on Photovoltaic Energy Conversion, vol. 1-2, 1994.

[34] A. Matsuda, Tetrahedrally Bonded Amorphous Semiconductors, pp. 192-196, American Institute of Physics, 1981.

[35] A. H. M. Smets, W. M. M. Kessels, and M. C. M. van de Sanden, "Vacancies and voids in hydrogenated amorphous silicon," Applied Physics Letters, vol. 82, no. 10, pp. 1547-1549, 2003.

[36] A. H. M. Smets and M. C. M. van de Sanden, "Relation of the $\mathrm{Si}-\mathrm{H}$ stretching frequency to the nanostructural $\mathrm{Si}-\mathrm{H}$ bulk environment," Physical Review B, vol. 76, no. 7, Article ID 073202, 2007.

[37] V. Smirnov, O. Astakhov, R. Carius, Y. Petrusenko, V. Borysenko, and F. Finger, "Variation in absorber layer defect density in amorphous and microcrystalline silicon thin film solar cells with $2 \mathrm{MeV}$ electron bombardment," Japanese Journal of Applied Physics, vol. 51, no. 2, Article ID 022301, 2012.

[38] V. Smirnov, O. Astakhov, R. Carius et al., "Performance of p- and n-side illuminated microcrystalline silicon solar cells following $2 \mathrm{MeV}$ electron bombardment," Applied Physics Letters, vol. 101, Article ID 143903, 2012.

[39] S. Nakano, "High absorption-coefficient and stable a-Si for high-efficiency solar cells," in Proceedings of the Conference Record of the 21st IEEE Photovoltaic Specialists Conference, vol. 2, pp. 1656-1661, Kissimmee, Fla, USA, 1990.

[40] W. E. McMahon, K. E. Emery, D. J. Friedman et al., "Fill factor as a probe of current-matching for $\mathrm{GaInP}_{2} / \mathrm{GaAs}$ tandem cells in a concentrator system during outdoor operation," Progress in Photovoltaics: Research and Applications, vol. 16, no. 3, pp. 213224, 2008.

[41] M. Matsumura, Y. Sakai, S. Sugahara, Y. Nakato, and H. Tsubomura, "Photoelectrochemical hydrogen evolution using amorphous silicon electrodes having $\mathrm{p}-\mathrm{i}-\mathrm{n}$ or $\mathrm{p}-\mathrm{i}-\mathrm{n}-\mathrm{p}-\mathrm{i}-\mathrm{n}$ junctions," Solar Energy Materials, vol. 13, no. 1, pp. 57-64, 1986.

[42] Y. Sakai, S. Sugahara, M. Matsumura, Y. Nakato, and H. Tsubomura, "Photoelectrochemical water splitting by tandem type and heterojunction amorphous silicon electrodes," Canadian Journal of Chemistry, vol. 66, no. 8, pp. 1853-1856, 1988.

[43] D. L. Staebler and C. R. Wronski, "Reversible conductivity changes in discharge-produced amorphous Si," Applied Physics Letters, vol. 31, no. 4, pp. 292-294, 1977.

[44] V. Smirnov, A. Lambertz, S. Tillmanns, and F. Finger, "pand n-type microcrystalline silicon oxide $\left(\mu \mathrm{c}-\mathrm{SiO}_{x}: \mathrm{H}\right)$ for applications in thin film silicon tandem solar cells," Canadian Journal of Physics, vol. 92, pp. 932-935, 2014. 

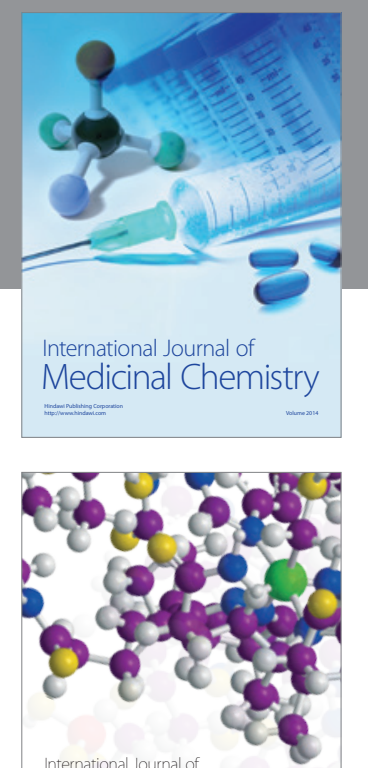

\section{Carbohydrate} Chemistry

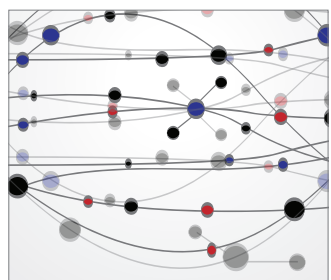

The Scientific World Journal
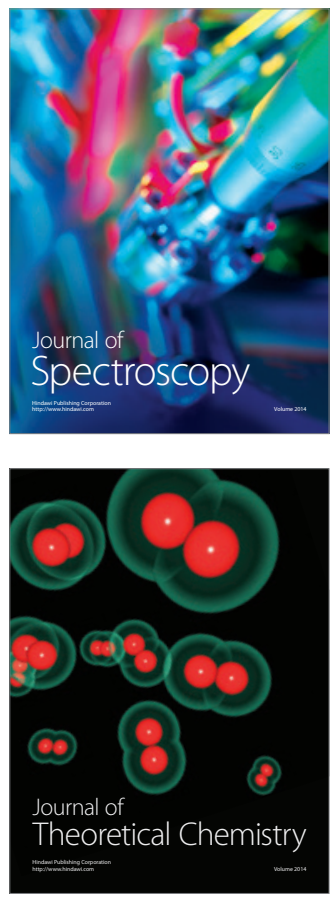
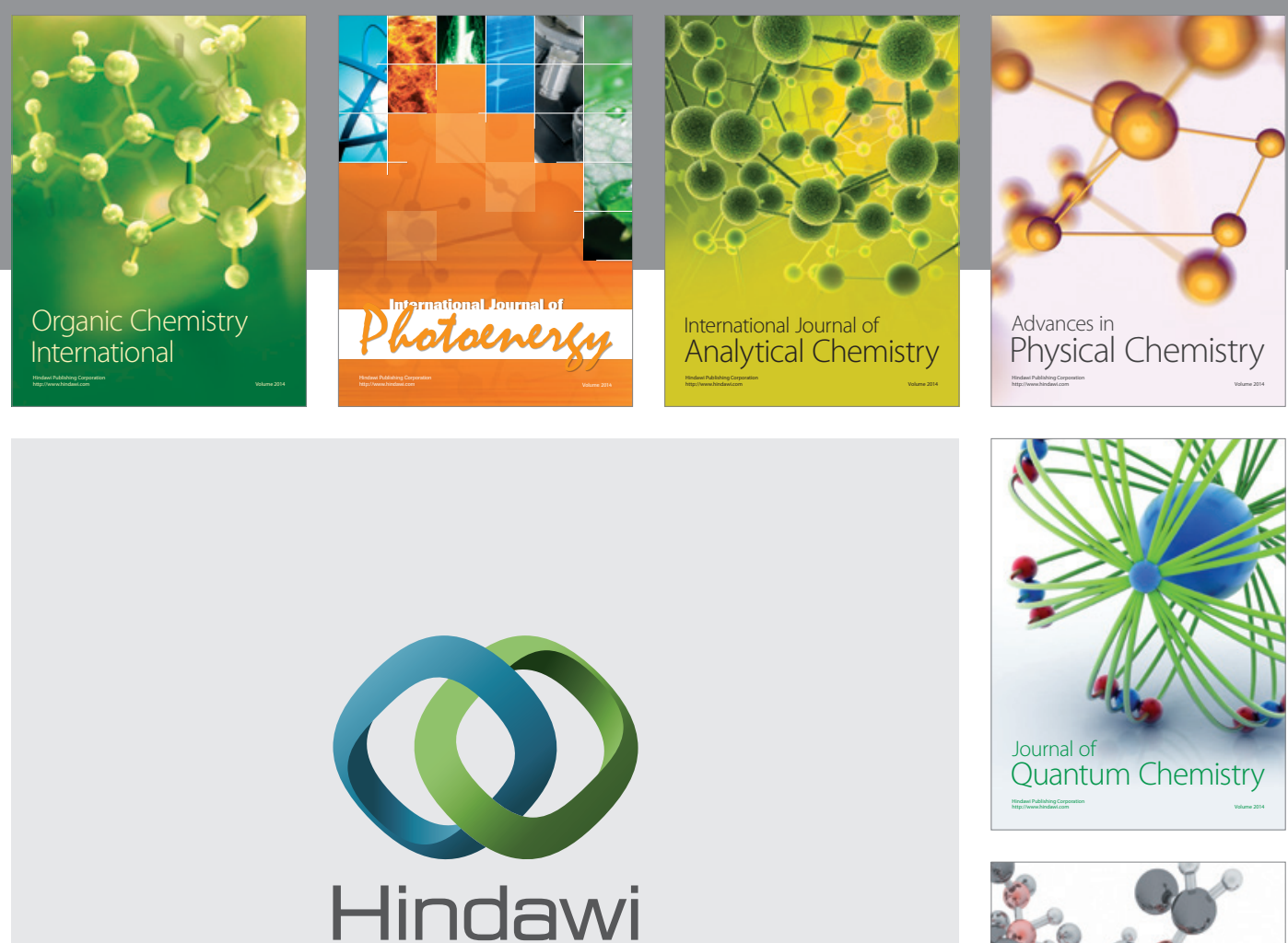

Submit your manuscripts at

http://www.hindawi.com

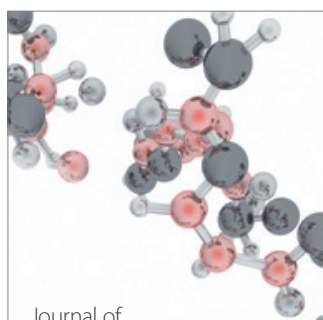

Analytical Methods

in Chemistry

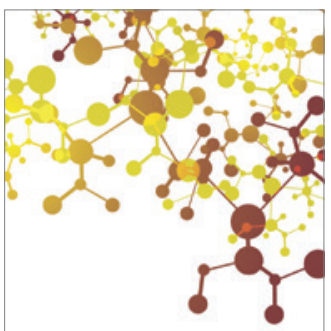

Journal of

Applied Chemistry

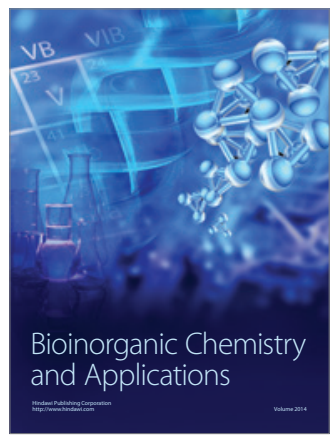

Inorganic Chemistry
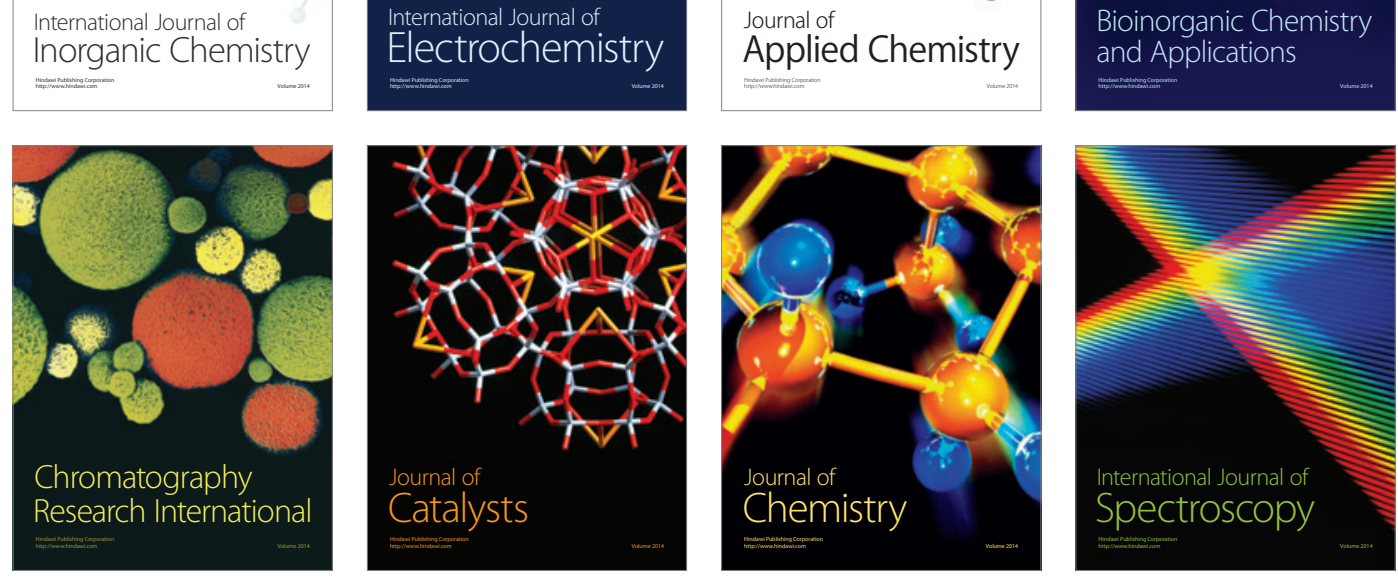